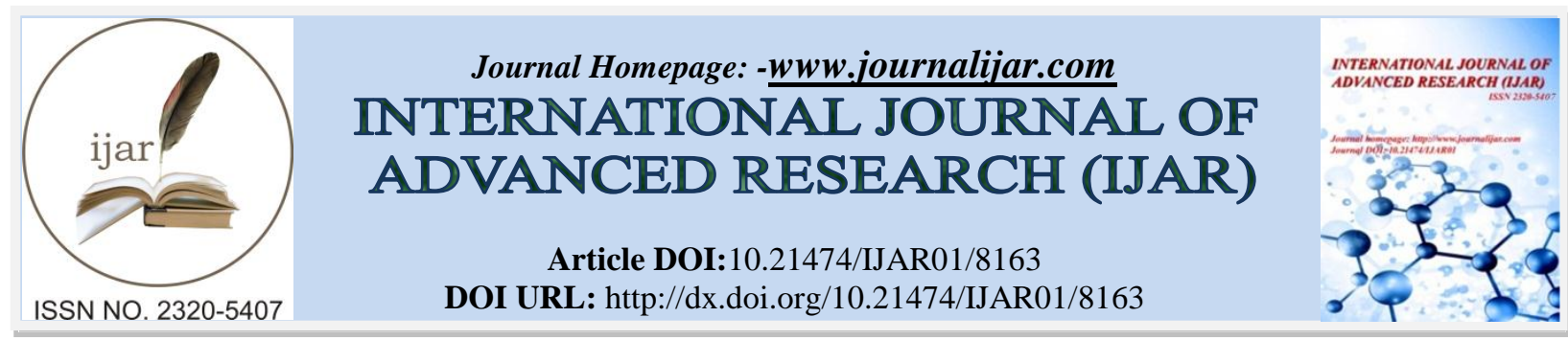

RESEARCH ARTICLE

\title{
COMPARATIVE STUDY OF IN VITRO ANTHELMINTHIC ACTIVITY OF ETHANOLIC EXTRACTS OF ALLIUM TUBEROSUM ROTTLER EX SPRENG. AND TRIGONELLA FOENUM GRAECUM L. ON INDIAN EARTHWORM.
}

Tarun Kumar ${ }^{1}$, A. Pfuzia ${ }^{2}$, Priyotosh Banerjee ${ }^{1}$ Priyadarshini Shougrakpam $^{1}$ and P. Shyamasakhi Devi ${ }^{3}$.

1. Post graduate junior resident, Department of Pharmacology Regional Institute of Medical Sciences, Imphal, Manipur, India.

2. Senior resident, Department of Pharmacology,Regional Institute of Medical Sciences, Imphal, Manipur, India.

3. Associate Professor, Department of Pharmacology, Regional Institute of Medical Sciences, Imphal, Manipur, India.

\section{Manuscript Info}

\section{Manuscript History}

Received: 04 October 2018

Final Accepted: 06 November 2018

Published: December 2018

\section{Keywords:}

Anthelminthic, Allium, Trigonella, Albendazole

\section{Abstract}

Helminths have infested human since the era of our earliest recorded history. As per the global estimate for the year 2010 about 465 million people were infested with round worms, hookworms, whipworms etc. So keeping this in our mind, a comparative study was done using ethanolic extracts of Allium tuberosum Rottler ex Spreng. (ATR) and Trigonella foenum graecum L. (TFG) plants for anthelmintic activity using Indian earthworm (Pheretima posthuma). Earthworms of 10-12 $\mathrm{cm}$ in length were washed with normal saline and divided into 6 groups with 6 earthworms in each group. Gum acacia $2 \%$ was used as control (group 1), albendazole suspension (20 $\mathrm{mg} / \mathrm{ml}$ ) as standard (Group 2), ATR $20 \mathrm{mg} / \mathrm{ml}$ and $40 \mathrm{mg} / \mathrm{ml}$ as group 3 and 4 and TFG $20 \mathrm{mg} / \mathrm{ml}$ and $40 \mathrm{mg} / \mathrm{ml}$ as group 5 and 6 . Time of paralysis and death of individual earthworms was recorded. The plants showed significant anthelminthic activity. Both ATR and TFG at $20 \mathrm{mg} / \mathrm{ml} \mathrm{\&} 40 \mathrm{mg} / \mathrm{ml}$ doses respectively showed comparable values in time of paralysis and time of death but less potent when compared to standard drug $(\mathrm{p}<0.001)$.

Copy Right, IJAR, 2018,. All rights reserved.

\section{Introduction:-}

Helminths is the word derived from the Greek word meaning "worms". ${ }^{1}$ Helminths have infected human since the era of our earliest recorded history. Many of the characteristic clinical features of helminthic infections can be recognised from the ancient writings of Hippocrates, Egyptian medical papyri and the Bible., ${ }^{2,4}$

As per the global estimate for the year 2010, about 438.9 million people were infected with hookworms (Ancylostoma duodenale), 819 million people were infected with roundworms (Ascaris lumbricoides) and 464.6 million people were infected with whipworms (Trichuris trichiura), which accounts for about a quarter of the world's population. ${ }^{5}$ Interestingly, Asia alone accounts for $70 \%$ of this burden and India being one of the largest contributors to the global burden with a national population prevalence of $21 \%{ }^{5}$ Helminths are more prevalent amongst children living in conditions of poor hygiene and their impact on morbidity and mortality is more severe in malnourished populations. ${ }^{6}$ As adult worms, the helminths survive in the human gastrointestinal tract for many

\section{Corresponding Author:-A. Pfuzia.}

Address:- Senior resident, Department of Pharmacology, Regional Institute of Medical Sciences, Imphal, Manipur, India. 
years. Most studies suggest that approximately $70 \%$ of the worm population is caused due to $15 \%$ of the host population. These infected individuals are the prime source of environmental contamination. ${ }^{7}$ Lack of adequate sanitary facilities with pure water supply coupled with poverty, illiteracy, lack of health education are some of the factors responsible for the widespread of this disease in developing countries like India. ${ }^{8}$ Helminths also affect domestic animals causing considerable economic loss. In the last few years, there has been an increase in the number of initiatives that aim to either reduce or eliminate the disease burden caused by helminthic parasites prevalent all over the world.

Manipur is a rich source of medicinal plants. The plants are used either separately or as poly herbal mixture and used by the local people in their ethnomedicinal system. ${ }^{9}$

There are few plants known to provide a rich source of phyto-anthelmintics in nature. Allium tuberosum Rottler ex Spreng.and Trigonella foenum graecum L. are known such plants having antihelminthic activity. Allium tuberosum Rottler ex Spreng. belongs to Liliaceae family. The local name is maroi nakupi and are used to treat indigestion, diarrhoea, headache and epilepsy by the local people. Sultana F et al ${ }^{10}$ revealed that Allium tuberosum is rich in polysaccharides, proteins, fibres, carbohydrates and on phytochemical screening, they found alkaloids, phenolic compounds, glycosides, proteins, saponins, flavonoids, tannins and steroids in it.

Trigonella foenum graecum L. of the family Fabaceae is commonly found in many parts of India, Asia and Middle east. It is known as fenugreek in English and as methi in Hindi. The seeds contain essential fatty oil 6\%, resin and mucilage $28 \%$, albumin $22 \%$, several alkaloids like choline, trigonelline, neurin, betain. It also contains flavonoids, steroidal saponins specially diosgenin, iron, plenty of fibres, non essential amino acids like 4-hydroxy isoleucin. In the Indian system of medicine Ayurveda, TFG was used as a tonic, carminative and to cure cold, sore throat, chronic cough, diarrhoea, dysentery, etc. ${ }^{11}$

Hence considering its use in treating gastrointestinal ailments for many years by the local people in different parts of the world, the present study was undertaken in vitro to compare the anthelminthic effect of ethanolic extracts of Allium tuberosum Rottler ex Spreng. and Trigonella foenum graecum L. with Albendazole on earthworm (Pheretima posthuma).

\section{Materials and Methods:-}

This comparative study was conducted in the Department of Pharmacology, Regional Institute of Medical Sciences, Imphal, Manipur. ATR and TFG plants were collected from the valley areas of Imphal West District, Manipur and authenticated from Department of Life Sciences, Manipur University, Canchipur as Allium tuberosum Rottler ex Spreng. species with Ac. No. MUMP 2531 and Trigonella foenum graecum L. species with Ac. No. MUMP 3627.

The plants were shade dried and powdered using mixer grinder and extracted with 95\% ethanol using soxhlet apparatus. The percentage yield of ATR was $14 \%$ and TFG was $12 \%$. Both the extracts were concentrated by evaporation at room temperature and were used for anthelminthic studies. The experiment was done in adult Indian earthworm (Pheretima posthuma) due to their anatomical and physiological resemblance with Ascaris lumbricoides. $^{12,13,14}$ The earthworms (10-12 cm in length) were collected from moist soil and authenticated from the Dept. of life sciences, Manipur University. They were washed with normal saline ( NS $0.9 \%$ ) to remove any filthy debris and then divided into six groups with six earthworms in each group. The $2 \%$ gum acacia was used as control (group1), Albendazole $20 \mathrm{mg} / \mathrm{ml}$ as standard (group2) and ATR $20 \mathrm{mg} / \mathrm{ml}$ and $40 \mathrm{mg} / \mathrm{ml}$ as group 3 and 4 , TFG 20 $\mathrm{mg} / \mathrm{ml}$ and $40 \mathrm{mg} / \mathrm{ml}$ as group 5 and 6 respectively. Standard \& test drugs were given as suspension in $2 \%$ gum acacia \& $10 \mathrm{ml}$ of desired formulation was used for each worm. Observation were made for the time taken for paralysis and death of individual worms. Time for paralysis was noted when no movement of any sort could be observed except when the worms were shaken vigorously. Time for death of individual earthworms was recorded when the worms showed no movement either by vigorous shaking or by dipping in the warm water $\left(50^{\circ} \mathrm{C}\right)$ followed by fading of their body colour. ${ }^{15}$

\section{Statistical analysis:-}

Data were analysed using One way ANOVA followed by Bonferroni test post HOC. Results were expressed in Mean \pm SEM. 


\section{Result and discussion:-}

The ethanolic extract of ATR and TFG at concentration $20 \mathrm{mg} / \mathrm{ml}$ and $40 \mathrm{mg} / \mathrm{ml}$ showed significant $(\mathrm{p}<0.001)$ anthelminthic activity when compared with albendazole $20 \mathrm{mg} / \mathrm{ml}$ (Table.1). It indicates that standard was better in reducing the time of paralysis and death. ATR and TFG at $40 \mathrm{mg} / \mathrm{ml}$ showed significant $(\mathrm{p}<0.001)$ anthelminthic activity when compared with ATR and TFG at $20 \mathrm{mg} / \mathrm{ml}$. It indicates that increasing the dose of the extract leads to decrease in the time of paralysis and death (Graph 1 and 2).

Table 1:-Comparative effect of ethanolic extracts of Allium tuberosum Rottler ex. Spreng and Trigonella foenum graecum L. on Indian earthworms.

\begin{tabular}{|c|c|c|}
\hline Group & Time of paralysis (in min) & Time of death (in min) \\
\hline 1.Control & - & ------------- \\
\hline 2.Albendazole $20 \mathrm{mg} / \mathrm{ml}$ & $4.51 \pm 0.186^{\mathrm{C}^{*} \mathrm{~d}^{*} \mathrm{e}^{\mathrm{x}} \mathrm{F}}$ & $20.07 \pm 0.17^{\mathrm{c}^{*} \mathrm{~d}^{*} \mathrm{e}^{\mathrm{x} f *}}$ \\
\hline 3.ATR $20 \mathrm{mg} / \mathrm{ml}$ & $10.43 \pm 0.25^{\mathrm{b} * \mathrm{~d}^{*} \mathrm{f} *}$ & $37.8 \pm 0.48^{\mathrm{b}^{* \mathrm{~d}^{* * *}}}$ \\
\hline 4.ATR $40 \mathrm{mg} / \mathrm{ml}$ & $8.2 \pm 0.13^{b * c^{*} e^{*}}$ & $26.27 \pm 0.17^{\mathrm{b}^{*} \mathrm{c}^{*} \mathrm{e}^{*}}$ \\
\hline $5 . T F G ~ 20 \mathrm{mg} / \mathrm{ml}$ & $9.53 \pm 0.19^{b^{*} d^{*} f^{*}}$ & $30.13 \pm 0.70^{\mathrm{b}^{*} \mathrm{~d}^{* \mathrm{f} *}}$ \\
\hline 6.TFG 40mg/ml & $7.42 \pm 0.20^{\mathrm{b} \mathrm{c}^{*} \mathrm{e}^{*}}$ & $25.62 \pm 0.41^{\mathrm{b}^{*} \mathrm{c}^{*} \mathrm{e}^{*}}$ \\
\hline
\end{tabular}

Results were expressed in Mean \pm SEM. Symbols b, c, d, e and $\mathrm{f}$ were used to compare with group 2, 3, 4, 5 and 6 respectively. ${ }^{*} \mathrm{p}<0.001$.

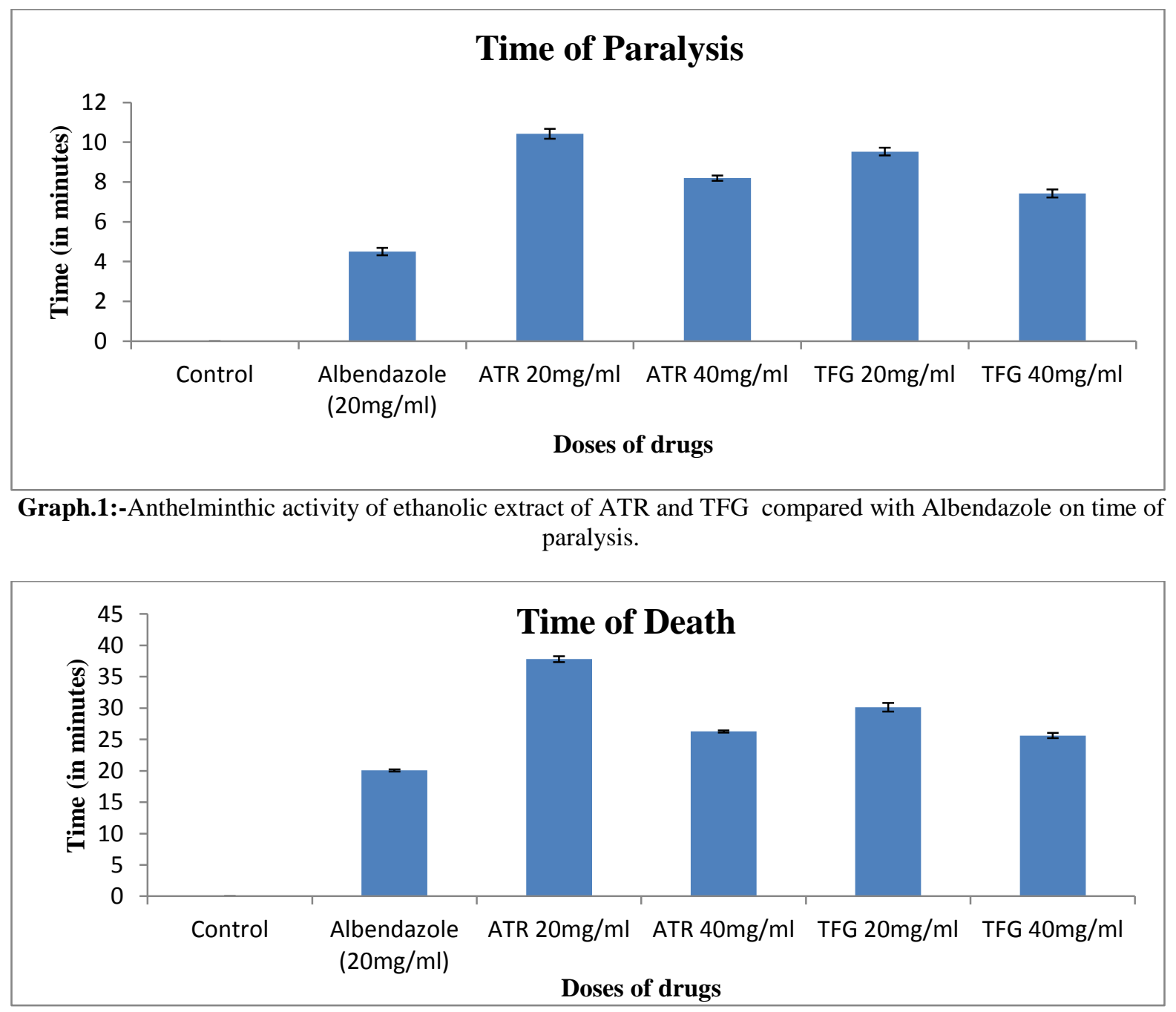

Graph. 2:-Anthelminthic activity of ethanolic extract of ATR and TFG compared with Albendazole on time of death. 


\section{Conclusion:-}

The ethanolic extracts of both ATR and TFG were found to possess anthelmintic activity when compared to albendazole but albendazole is more potent at the given dose. Both ATR and TFG showed comparable anthelminthic activity at equivalent doses but found to be more effective at higher dose. Further studies of the plants may be explored to isolate the active compounds accountable for anthelminthic activity and to find out the mechanism of action.

\section{References:-}

1. Faust EC, Russell PF, Jung RC, editors. Craig and Faust's clinical parasitology. 8th edition. Philadelphia: Lea \&Febiger; 1970.

2. Cox FEG. History of human parasitology. ClinMicrobiol Rev 2002;15(1):595-612.

3. Hotez PJ, Ottesen E, Fenwick A, Molyneux D. The neglected tropical diseases: the ancient afflictions of stigma and poverty and the prospects for their control and elimination. AdvExp Med Biol 2006;582(1):23-33.

4. Hotez PJ. Forgotten people and forgotten diseases, the neglected tropical diseases and their impact on global health and development: ASM Press; 2008

5. Pullan RL, Smith JL, Jasrasaria R, Brooker SJ. Global numbers of infection and disease burden of soil transmitted helminth infections in 2010. Parasit Vectors 2014;7(37):1-19.

6. Brooker S, Clements A, Bundy DAP. Global epidemiology, ecology and control of soil-transmitted helminth infections. AdvParasitol 2006;62(1):223-65.

7. Bundy DAP, de Silva NR. Can we deworm this wormy world? Br Med Bull 1998;54(1):421-32.

8. De Silva NR, Brooker S, Hotez PJ, Montressor A, Engels D, Savioli L. Soil-transmitted helminth infections: updating the global picture. Trend Parasitol 2003;19:547-51.

9. Yumnam RS, Onita CH, Abujam SKS, Chetia D. Study on the Ethnomedicinal System of Manipur. IJPBA 2012;3(3):587-91.

10. Sultana F, Mohsin M. Nutritional Screening of Allium tuberosum from Western Himalayan Region of India. Int $\mathrm{J}$ of Sci and Res 2012;1(1):727-31.

11. Valette G, Sauvaire Y, Braccou TC, Ribes G. Hypercholesterolemic effects of fenugreek seeds in dogs. Atherosclerosis 1984;51(1):105-11.

12. R.D. Vidyarthi. A Textbook of Zoology. 14th edn. New Delhi: S. Chand and Co; 1977.

13. G.W. Thorn, R.D.Adams, E.Brundwald, K.J. Isselbacher, R.G.Petersdorf, editors. Harrison's Principles of Internal Medicine. New York: McGrow Hill; 1977.

14. Z.Vigar. Atlas of Medical Parasitology. $2^{\text {nd }}$ edn. Singapore: P.g. Publishing House.

15. R.G.Mali, J.C.Hundiwale, R.S.Sonawane. Indian J Nat Prod 1995;14(1):11. 